\title{
Mass Media Analysis: Contribution of Millennials in the Success of the 2019 Election in Indonesia
}

\author{
Uli Asniati Fajri ${ }^{1}$, Riska Sarofah ${ }^{2}$, Yusuf Fadli ${ }^{3}$, Arif Ginanjar Suryatman ${ }^{4}$, Ahmad \\ Chumaedy ${ }^{5}$ \\ ${ }^{1}$ Department Government of Science, Universitas Muhammadiyah Tangerang, Indonesia \\ ${ }^{2}$ Department Government of Science, Universitas Muhammadiyah Tangerang, Indonesia \\ ${ }^{3}$ Department Government of Science, Universitas Muhammadiyah Tangerang, Indonesia \\ ${ }^{4}$ Department Government of Science, Universitas Muhammadiyah Tangerang, Indonesia \\ ${ }^{5}$ Department Government of Science, Universitas Muhammadiyah Tangerang, Indonesia \\ ${ }^{1}$ Corresponding Author: uliasniatifajri24@gmail.com
}

\section{Article Info}

\section{Keyword:}

Political Participation;

Millennials;

Elections.

\section{Kata Kunci:}

Partisipasi Politik;

Millennial;

Pemilu.

\begin{abstract}
The success of general elections has an important objective in the quality of election administration. The influential millennial factor has a dominant tendency towards political power to make a major contribution to candidate candidates in the 2019 elections in Indonesia. With the increase in the political participation of millennials, it provides significant value in determining voting rights as a form of millennial contribution action and becomes the benchmark for the next election for political parties and candidate candidates. Thus the researchers used qualitative methods with descriptive analysis techniques of the Nvivo 12 plus application using the features of Crosstab Analysis, Cluster Analysis, Concept Map and Project Map Analysis, and Discourse Analysis. There are 3 process stages, the first is Ncapture website and articles, the second stage is analyzing with Nvivo 12 plus to interpret text and content that have the same meaning, words, and context that make the website and article interrelated; The third stage of discourse analysis is the analysis and meaning of relevant website content and articles. The conclusion of this research is to know the contribution of millennials to the success of the 2019 elections in Indonesia.
\end{abstract}

\begin{abstract}
Abstrak: Mensukseskan pemilihan umum memiliki tujuan yang penting dalam kualitas penyelenggeraan pemilu. Faktor kaum milleninial berpengaruh memiliki kecendrungan dominan terhadap kekuatan politik memberikan kontribusi besar bagi kandidat calon dalam pemilu 2019 di Indonesia. Dengan peningkatan partisipasi politik kaum millennial, memberikan nilai yang signifikan dalam menentukan hak suara sebagai bentuk tindakan kontribusi millennial serta menjadi tujuan tolak ukur untuk pemilu selanjutnya bagi para partai politik dan kandidat calon. Demikian peneliti menggunakan metode kualitatif dengan Teknik analisis deskriptif aplikasi Nvivo 12 plus menggunakan fitur Crosstab Analysis, Cluster Analysis, Concept Map dan Project Map Analysis, dan Discourse Analysis. Ada 3 proses tahapan, pertama Ncapture website dan artikel, tahap kedua menganalisis dengan Nvivo 12 plus untuk memaknai text dan konten yang memiliki kesamaan makna, kata-kata serta konteks yang membuat saling berkaitan antara website dan artikel; tahap ketiga discourse analysis yaitu analisis dan pemaknaan content website dan artikel yang relevan. Kesimpulan dari penelitian ini mengetahui kontribusi kaum millennial dalam mensukseskan pemilu 2019 di Indonesia.
\end{abstract}

Article History: Received: 2020-08-28, Revised: 2020-10-26, Accepted: 2020-10-28 


\section{INTRODUCTION}

Every citizen's right to participate in political participation with the aims and objectives of each individual who has political awareness. Indirectly participating in elections has an important role to play in building the nation and state (Hani S.P, 2013). General elections or elections are an instrument that embodies the sovereignty of the people, and in the form of technical implementation it requires specific rules so that elections are not a guarantee of democracy itself, but elections are a way to get legitimacy to overpower for regime people. in government (Efriza, 2015). According to (Fitri, 2018) explaining that "elections are not just getting legitimacy but a mechanism to elect a leader informal institutions such as the executive, legislative, judiciary at the regional and central levels."

Elections are the most important for the fulfillment of three democratic principles in government, namely the sovereignty of the people, the legitimacy of government, and regular changes in government. Election as a forum for realizing democracy as a suggestion and an ideal mechanism in the process of transferring power in a peaceful and orderly manner. With the implementation of elections, it is hoped that the process of transferring power in a country is going well (Ansori, 2017).

In the past, Indonesia carried out a simultaneous general election democracy in which the election of candidates for President and Vice President of the Republic of Indonesia and legislative elections were held simultaneously on April 17, 2019. A new thing in a democratic party is carried out by all Indonesian people to vote and participate in elections. The conception of simultaneous elections was decided by the Constitutional Court on January 23, 2014, that the implementation of the Presidential and Vice-Presidential Elections, as well as the Legislative General Elections, will be held simultaneously starting in 2019 (Nuryanti, 2015).

Millennials are known as generation Y. Demographic groups after the existence of generation X. In the early 1980s, this generation was the beginning of the birth of this group, so that in the 2000s it was the last group born in that generation. Millennials are generally the children of the Baby Boomers generation and the older X generation. Millennials are referred to as "Echo Boomers" because of the increasing number of births in the 1980s-1990s. Millennial characteristics based on regional and socio-economic conditions experience different things, but this generation can generally be marked by an increase in the use and familiarity of using media communication and digital technology (Satria, 2018).

The population of millennials in Indonesia is around 34.5 to 50 percent which is based on the total population with vulnerable ages of 15-35 years. This figure shows a very significant size so that millennial voters will become an important target group in the success of the general election. Millennials use digital media to know and understand politics with social media such as Twitter, Facebook, YouTube, etc., so that they can shape their perceptions in politics (kompasiana.com, 2019b).

The characteristic of millennials is that there is a tendency to be rational and consciously start participating in the 2019 elections. According to Sarah Nuraini Siregar, based on the results of the LIPI survey, there is around 35 percent to 40 percent of voters in the 2019 election who are dominated by the millennial generation with around 80 million of them. 185 million voters (Abdi, 2018).

According to the Voxpop Center political observer Pangi S Chaniago, the millennial generation that was formed as a creative, confident, disloyal nature and does not want to be a political object. As is known, social media cannot be separated from the millennial generation, so it can influence votes in general elections (Baderi, 2018). Millennials are known as targets of politicians to carry out strategies as target objects in voting (Media Kompas, 2018). Millennials have the potential to become political forces with their large numbers, so the votes of millennials can make a significant contribution to presidential candidates (Mochtar, 2019).

The millennial distribution map focuses on some votes acquired by the millennial group, so it requires information based on the geographic map of Indonesia, the distribution of their points, here are some of the distribution of Indonesian millennial projections. 
Table.1 Projection of Millennial Distribution in Indonesia

\begin{tabular}{llcc}
\hline \multicolumn{2}{c}{ PROJECTION OF MILLENNIAL DISTRIBUTION IN INDONESIA } \\
\hline No & Province & Percentage & Millennials \\
I & West Java & $18,77 \%$ & 11 Million Population \\
II & East Java & $13,80 \%$ & 8 Million Population \\
III & Central Java & $11,91 \%$ & 7 Million Population \\
IV & North Sumatra & $5,34 \%$ & 3 Million Population \\
V & Banten & $5,23 \%$ & 3 Million Population \\
VI & DKI Jakarta & $4,25 \%$ & 2 Million Population \\
VII & South Sulawesi & $3,34 \%$ & 2 Million Population \\
\hline
\end{tabular}

Source: (Tirto.id, 2018)

Based on the table.1 of the Indonesian territory, the millennial projections are based on the existence of grouping with the position of West Java province with a total of around 18.77 percent of the millennial group (11 million population), East Java with a total of 13.80 percent with a range ( 8 million population), then North Sumatra written with a total of 5.34 percent (3 million population votes). Based on the fifth position of the millennial group in the Banten region with a total of 5.23 percent ( 3 million population) and the sixth position of DKI Jakarta with the proportion of each and 4.25 percent of the total number ( 2 million population) Meanwhile, the position of the seven regions South Sulawesi with a total of about 3.34 percent ( 2 million population) of the millennial group and constituting the largest percentage in Sulawesi. (Tirto.id, 2018)

Millennials and Race in the 2016 Election, Vladimir Enrique Medenica, University of Chicago, Journal of Race, Ethnicity and Politics, 3, 55-76, 2018 (Medenica, 2018). This study used a qualitative method. This journal explains that millennial voters do not have much chance in the election of Barack Obama. The existence of diverse races and ethnicities of millennial generations in history has whites standing out as the exception in their generation. In 2016 the election of Donald Trump as a white voter had several influencing factors such as alignments, ideology, racial hatred, education, and income.

Political Participation of Millennial Generation on Instagram in the 2019 Election, Nadia Laksmitha K, Eko Harry Susanto, Tarumanagara University (2019), Connections, Vol. 3 No.1, July 2019 (Laksmitha \& Susanto, 2019). This study uses a qualitative method. Millennial generation journals like political participation by means that through social media Instagram has been used widely and massively by millennials to interact and communicate about the 2019 general election well without having to show their personality attributes openly.

Review of Millennials' Insights Facing the Implementation of the Democratic Party, Rian Sacipto, Ngudi Waluyo University, Adil Indonesia Jurnal, Vol. 1 No. 1 (2019) (Sacipto, 2019), This research uses a qualitative method. This journal explains that students as the millennial generation are looking for information and news obtained from television, internet, social media related to the implementation of a democratic party, but sometimes it is not necessarily possible to directly control the accuracy of the news and information. With this, students can participate in the success of the election as well as members of the TPS or witnesses when holding a democratic party so that it runs smoothly.

Level of Political Participation of Beginner Voters in the Implementation of the 2014 Legislative Election DPRD Sampang, Mister and Agus Satmoko Adi, Surabaya State University, Vol. 1, No. 3, Hal 1-20 (2015) (Mistar \& Satmoko Adi, 2015), This research uses quantitative methods. The results of the study of the total sample size of 116 participation of novice voters in East Ketapang village were classified as very high with a percentage result of $86.21 \%$ in the very important category or very high participation. Some novice voters abstained, namely only $13.79 \%$ of first-time voters who did not participate in voting. One of the factors that can influence new voters in participating in the 2014 legislative elections is due to the awareness, belief, and encouragement of others. So that it can lead someone to participate in the implementation of the 2014 legislative elections in East Ketapang Village, Ketapang District, Sampang Regency. 
Taiwan's Millennial Generation: Interests in Polity and Party Politics, Brading, Ryan, Eberhard Karls University, Journal of Current Chinese Affairs, Vol 46, No 1, (2017) (Brading, 2017), This research uses quantitative methods. Based on the results of the study, that political participation will increase the number of people who will vote in the election, with this what the millennial generation in Taiwan does require a change in the democracy of the presidential election to build a very important role in convincing young people or the millennial generation of politics. Because this shows that the majority of young people in Taiwan have little interest in political participation.

According to (Al Walidah, 2017) explaining Millennial is "the term cohort in demography, which is a noun meaning as a follower or group. There are four generations in a demographic, namely the Baby Boomer generation born in 1946-1964, Generation X having births in 19651980 , then the millennial generation who were born in the early 1981-2000 years, and the last Generation Z was born in 2001 until so on. "

According to (NW et al., 2014), the life of the millennial generation cannot be separated from information technology, especially the internet and likes some entertainment, culture, or music which have become basic needs. Millennials are often considered the generation who least care about political issues. According to (EACEA, 2012), "This generation is relatively few in participating in political parties. Millennials will prefer not to participate in determining their voting rights in elections".

According to (Surya Putra, 2016) explaining "Generation Y or what is called the millennial generation. Starting from Generation Y, it began to be used in the editorial of major US newspapers in August 1993. So that Generation has used information technology in communication such as email, SMS, instant messaging, and social media such as Facebook and Twitter, etc. Thus it is that generation Y will grow up in the internet booming era ".

So with this, the millennial generation has an important role in information technology media, considering that this group is very influential with their very large number. This is so that the millennial generation influences political participation in political activities or general elections. As the millennial generation also has the right to choose to determine a leader.

According to Taylor and Keeter in (NW et al., 2010), the characteristics of a generation can be determined through at least three times in the overlapping process, namely:

1. Life cycle, millennials make up a large part of the young population who have several different characters because they have grown older and older, and they have the same characteristics as other generations.

2. The period effect, each generation has a period accompanied by several social, political, cultural, technological, and other contexts.

3. The labeling effect, this generation has academic wear, will form a characteristic character.

According to Sigit Pamungkas, explaining "Elections are places of competence in political positions in government, which are based on the choice of citizens to fulfill their rights as election participants and political parties that will be able to nominate candidates in elections will then be elected by the people." (Efriza, 2012) According to (Labolo \& Ilham, 2015) states that "Elections are a method of obtaining a vote in a general election which results in winning seats in every parliamentary party and candidate. As the general election becomes an important means in the process of selecting people's representatives to work on behalf of the state policymaking."

Election administration principles constitute a set of value systems that can be desired by law to produce election administration with integrity. According to the International Institute for Democracy and Electoral Assistance (IDEA) (Wall et al., 2016) explains the main principles in holding elections, namely:

1. Independent Institution, the election organizer has an independent attitude which can be shown through the ability of the organizers to be free from any political interest and pressure.

2. Impartiality, election organizers must show attitudes and actions that are not based on indicating partiality to election participants, either parties or candidates. 
3. Integrity, election administrators are required to have a strong personality and commitment to carry out their duties and authority in controlling the election process following the rules and legal norms in force.

4. Transparency. With the guarantee of transparency, election participants and the public can access information about election administration in terms of budget, policy, and accountability for the overall implementation of the election.

5. Efficiency, this principle emphasizes the appropriateness of the implementation in making the design of an election that is right on target, the budget is made according to the right needs, is wise, and prioritizes quality aspects in carrying out the implementation.

6. Professionalism, election administrators must have figures who are experts and master electoral issues, based on candidates who have high qualifications as commissioners and prioritize common interests to make elections with integrity.

7. Service-oriented, election administrators are required to provide services by prioritizing all parties (Parties, Candidates, and Communities) and prioritizing work governance that can be accounted for from a legal aspect (Legal Framework) (Surbakti \& Nugroho, 2015).

In the success of the election, it is necessary to have indicators to be stated as the quality of success in the election. As it is known, an integral part of an election organizer with integrity reaches an absolute requirement for the creation of quality elections. According to IDEA (Delmana et al., 2019), there are fifteen indicators of election quality, namely: Formulation of the legal framework, electoral system, determination of boundaries, district and definition of unit election boundaries, the right to vote and be elected, electoral management bodies, voter registration and voter lists, ballot access for political parties and candidates, democratic election campaigns, media access and freedom of expression, campaign financing and spending, voting, counting and tabulating votes, the role of representatives of parties and candidates, election observers and compliance with law enforcement -Election invitation.

Participation is involvement with individuals participating in various activities in political life. Each right has participation in the form of giving or not providing political support in any activity, especially in terms of campaigns or voting in general elections and participating in the process of determining political policies. So political participation is a form of participation in the efforts made by the community, whether each individual or group can determine all decisions, participate in influencing the process of forming public policy in a country (Andriadi, 2016).

According to Kevin R. Hardwick explained that "Political Participation is giving attention to citizens to interact with the government, as well as efforts to convey their interests to political officials in government to realize these interests." (Efriza, 2017)

Meanwhile, according to Samuel P. Huntington and Joan M. Nelson, "Political participation is an activity of citizens that is part of the actions of individuals who are meant to influence decision-making by the government. And participation can also be individual or collective, organized or spontaneous, steady or sporadic, peaceful or violent, legal or illegal, effective, or ineffective. " (Anwar, 2014)

According to Ariadne Vromen (Kumparan.com, 2018), there are three characteristics of millennial political participation, namely:

1. Digital approach, through a digital approach, you can participate in the form of petitions, donations, join discussion forums, and digital media which are the first to invite youth to enter politics.

2. Issues, Millennials who are familiar with information technology can look for new or viral issues to be discussed for the millennial generation. As well as issues of climate change issues. Identity, gender, and about the importance that concerns and is relevant to him.

3. Individualists, Millennials can be people who care about various issues around them, however, this cannot be ascertained in line with Vromen's findings that young people are increasingly individualistic. Based on the research above, the researcher focused on 
the research problem, how is the Contribution of Millennials in the Success of the 2019 Election in Indonesia?

\section{RESEARCH METHOD}

In this qualitative research using descriptive analysis. The research was conducted based on the analysis of online media content and the interpretation of texts with existing situations and phenomena. Content analysis was conducted through several online media, namely Kompasiana.com, Kompas.com, Kumparan.com, Republika.co.id, Tirto.id, and Neraca.co.id.

This research is a descriptive analysis conducted using the Nvivo 12 Plus software. Data analysis used the Nvivo 12 Plus application with features of crosstab analysis, concept map analysis, and text research analysis (Brandao, 2015). Data collection techniques with data sources in the form of journal articles, relevant and reputable websites provide news information based on the results of interviews with several informants related to the contribution of millennials in the success of the 2019 elections in Indonesia.

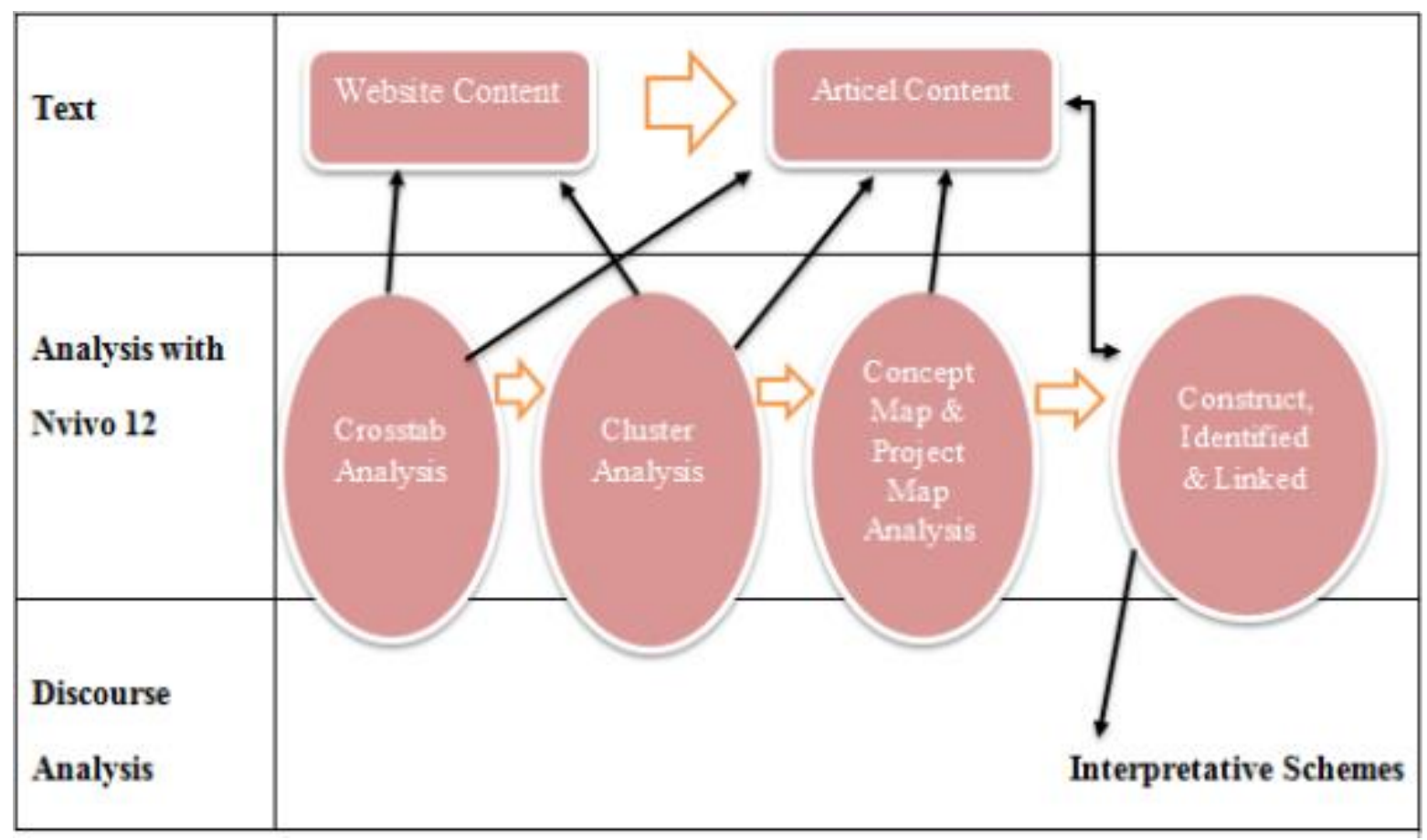

Figure.1 Stages of Research and Data Analysis

Source: (Processed by the author, 2020)

Based on the figure. 1 process stages in the analysis of the first Nvivo 12 Plus application, there is text. Text is a collection of relevant website content or article content to be used as data. Second, analysis with Nvivo 12 plus, there are 4 process stages. Crosstab analysis is the process of making contingency tables in a multivariate variable frequency distribution and presented in a matrix format. Cluster Analysis is a mapping of indicators from several relevant content websites or article content. Concept Map and Project Map Analysis are mapping the concept of thought so that it becomes propositions in variables. Construct Identified and Linked is a mapping done structurally based on the data that has been collected before the analysis and meaning of words. Finally, Discourse Analysis is an analysis and meaning of each word from the relevant website content or article content which is then used as research data.

\section{RESULT AND DISCUSSION}

Political participation is the beginning of a democracy that invites many people to participate in general elections both at the regional level or national level elections simultaneously throughout Indonesia. Thus, political participation can be through invitations or 
socialization of various other parties to participate in determining their voting rights and can become part of the holding of general elections.

In Indonesia, the millennial generation is a very important discussion group when it comes to general elections. In the 2019 elections in Indonesia, millennials contributed a lot, such as participating in discussions in various forums, having opinions through social media, and organizing the 2019 elections and others. The number of millennial generations in Indonesia is quite large. If millennial political participation is considered very significant if they can get political voting rights in determining their choices. Several factors influence millennial political participation based on their different characters from each other generation and often do not care about the discussion leading to politics.

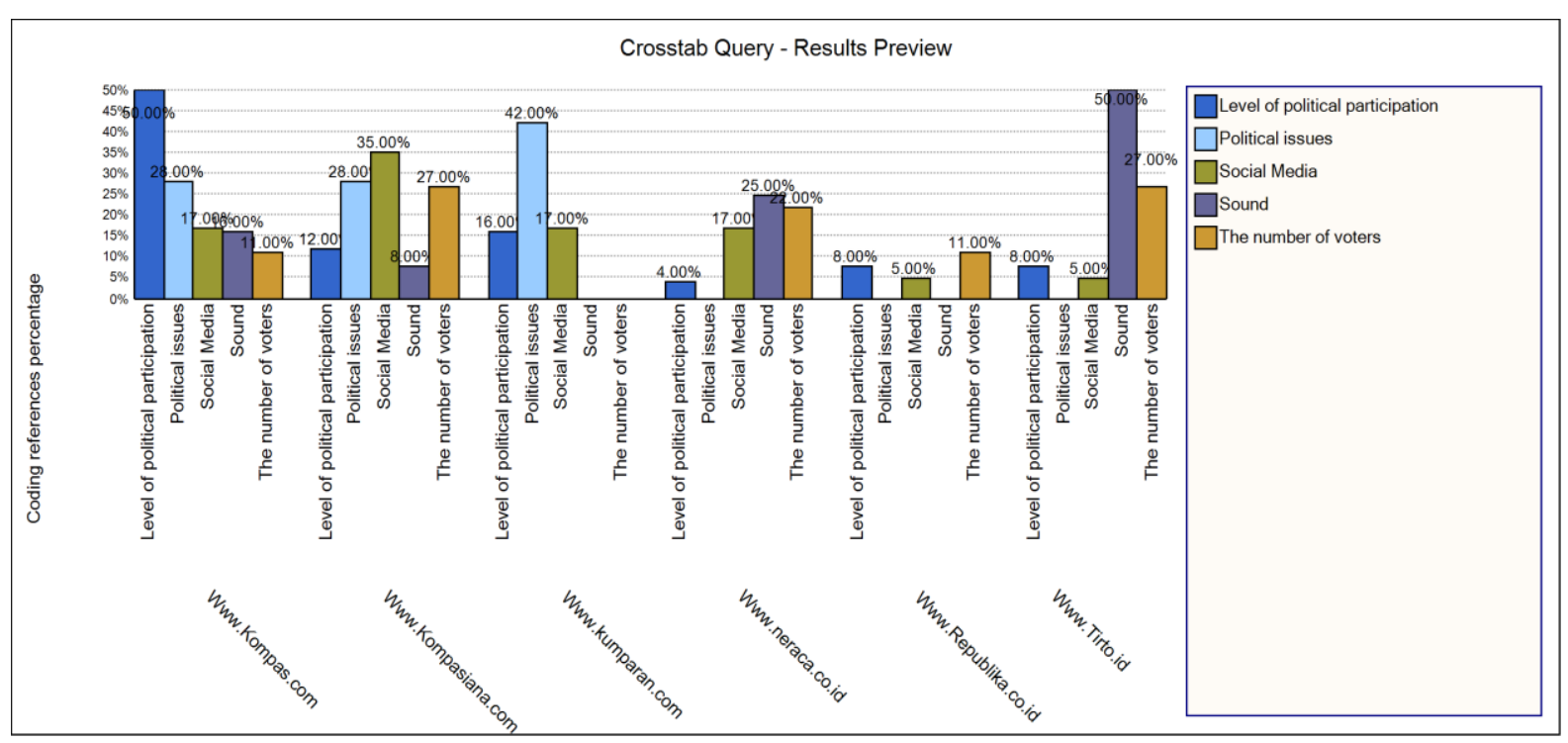

Graph.1 Influencing factors

Source: (Crosstab Query Analysis with Nvivo 12 Plus, 2020)

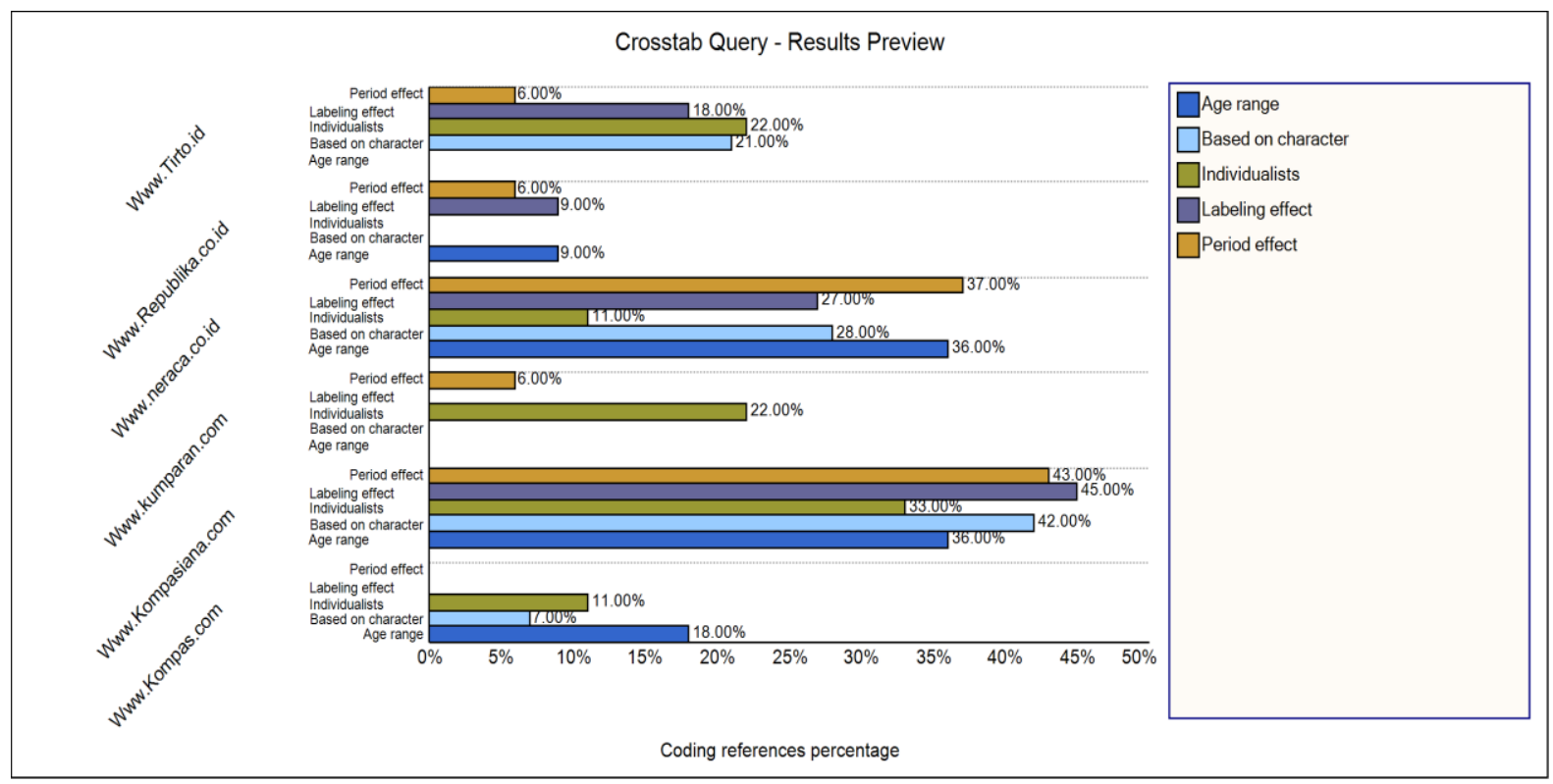

Graph.2 Influencing factors

Source: (Crosstab Query Analysis with Nvivo 12 Plus, 2020)

In graph.1 and graph.2 above, some of the crosstab analysis results have a dominant tendency towards indicators in accordance with my theory. The following is the result of crosstab analysis, on the news www.tirto.co.id explains that there are several indicators that 
have a dominant tendency to influence, period effect with the percentage result $6 \%$, labelling effect percentage result $18 \%$, individualist the percentage result $22 \%$, and based on character with the percentage result $21 \%$. And then on the news www.republika.co.id period affect the percentage result $6 \%$, labelling effect with percentage result $9 \%$, and age range the percentage result $9 \%$. Some of the result on the news ww w.neraca.co.id explains that there are several indicators that have a dominant tendency to influence, period effect with the percentage result $37 \%$, labelling effect percentage result $27 \%$, individualist percentage result $11 \%$, based on character percentage result $28 \%$, and percentage result age range with value $36 \%$. On the news www.kumparan.com several indicators that have a dominant tendency to influence, period effect percentage result $6 \%$, and individualist with the percentage result $22 \%$. On the news www.kompasiana.com several indicators that have dominant tendency influence, period effect with percentage result $43 \%$. On the news www.kompas.com, several indicators that have dominant tendency influence, individualist with percentage result $11 \%$, based on character with percentage result $7 \%$, and age range with percentage result $18 \%$.

The millennial characteristics are the factors that affect the contribution of millennials in the success of the 2019 elections in Indonesia. The first indicator is based on character, that from each other generation there are differences in how to do something and behave and the main character is how to distinguish the characteristics of someone. Millennials are considered to be a change in carrying out movements such as during the 2019 election in Indonesia, millennials become the discussion of political objects. Because millennials are judged critical way of thinking so that it can be the material for their discussion in the forum. Thus, millennials are the main ones in obtaining votes in the 2019 election in Indonesia. Second, the labeling effect. According to (NW et al., 2010) the effect of labeling is something that is possessed by every millennial generation where their academic projections can shape their characteristics. The label that is owned by the millennial generation with the majority population and this generation is the key to the formation of today's society in the next few years.

Millennial technological advances affect the millennial generation, especially how to communicate and interact with each other. Millennials tend to use social media as their life who cannot be far from technology just as millennials participate by using any media to support the choice of candidate candidates in the 2019 election, discuss via online media or in person, and determine their voting rights. In this context, there are several general characteristics of the millennial generation that have characteristics, namely connected, creative, confident, and open to change. Third, the period effect. In this discussion, the millennial generation has experienced every other generation before it. If we look at the differences in terms of economic, sociopolitical, technological, and other contexts with changing developments. The context in Indonesia regarding the study of the millennial generation is very important to discuss in demographics, politics, and technology. First, the demographics in Indonesia based on (BPS, 2013), population census in 2010-2035 projections of Indonesia's population in 2018 will amount to a total of $265,015,300$ people. Because more than $35 \%$ of Indonesia's population is young people aged 15-34 years (Amarullah \& Firmansyah, 2018). Indonesia will experience demographics in 2020, 2025, 2030. This means that Indonesia's young population will be more dominant. Second, in the political context because 2018 and 2019 will be important years for politics because Indonesia will hold legislative and executive elections simultaneously. According to the 2019 election voter data, the KPU explained that there were 196,545,636 people and nearly half of the voters were millennial generation. According to research results (Charta, 2018), Indonesia shows that in the 2019 election, $47-50 \%$ of election participation was the millennial generation. Because the involvement of the millennial generation in politics is very high and significant. Third, technological developments. High population and political constellations color the rapid progress of information and communication technology giving a different touch to the involvement of millennials in the life of the nation and state.

Based on millennial characteristics, there are several variables stated as indicators that also influence certain contexts. First, Individualists. This means that millennials often become individualistic, such as using technology for a long time using social media; this will have the effect of feeling individual and indifferent to the environment, as well as the apathetic behavior 
of the millennial generation who do not care about politics. However, millennials prefer to volunteer in their environment and discuss improving their careers rather than getting involved in politics which they think are not interested. Second, the age range. In the millennial generation born in 1980-2000, around the age of 15-34 years, this age vulnerability affects the context of the 2019 elections in Indonesia. Beginner voters in the 2019 election, including the millennial generation, are influential in determining their voting rights because first-time voters are the main role who will only elect candidates in the 2019 elections.

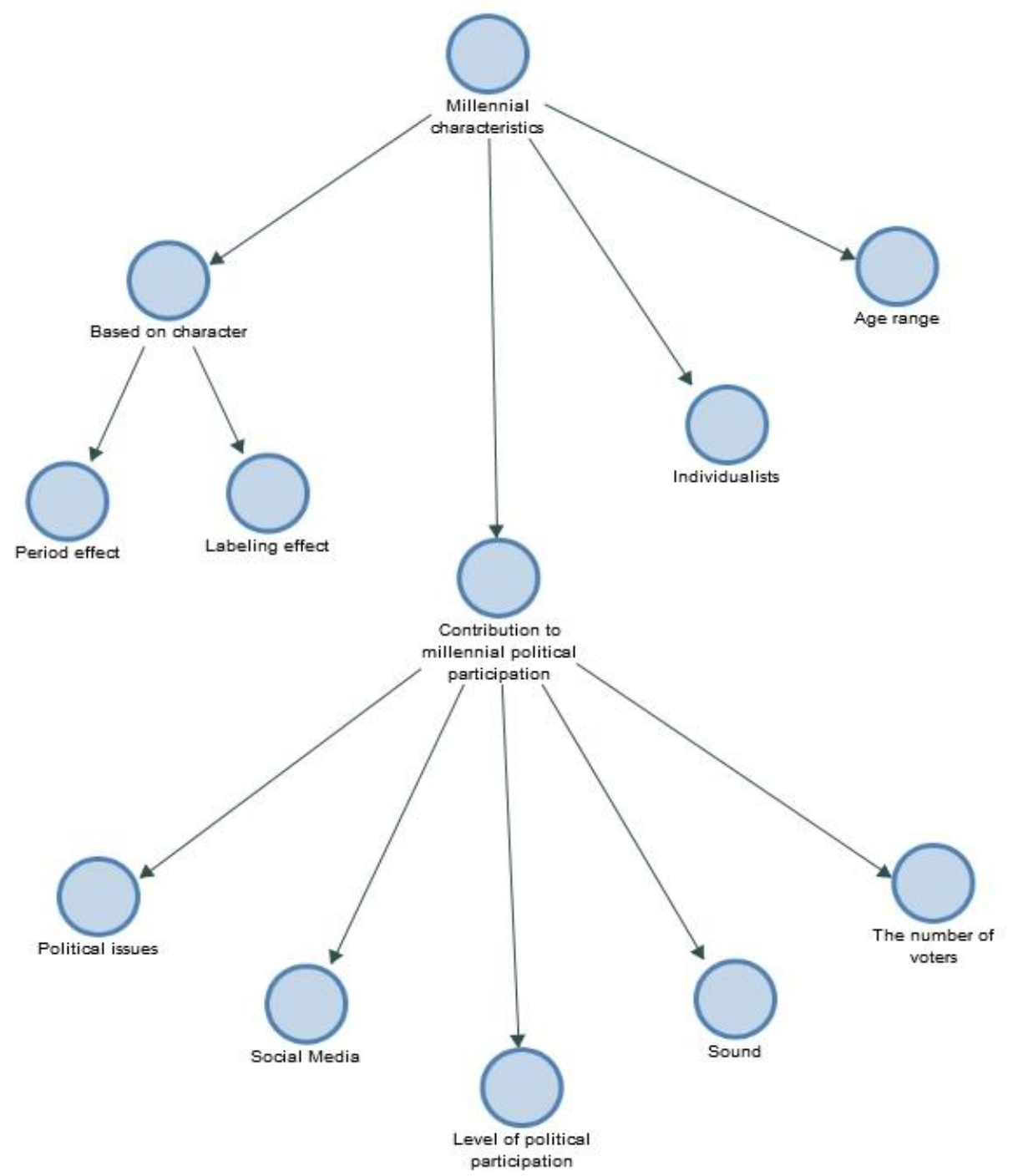

Figure.2 Concept Map

Source: (Concept Map with Nvivo 12 Plus, 2020)

On the figure. 2 above that, some of the crosstab analysis results have a dominant tendency towards indicators in accordance with my theory. The following is the result of crosstab analysis, on the news www.tirto.co.id explains that there are several indicators that have a dominant tendency to influence, level of political participation with the percentage result $8 \%$, social media percentage result $5 \%$, sound with the percentage result $50 \%$, and the number of voters with percentage result $27 \%$. And then on the news www.republika.co.id level of political participation the percentage result $8 \%$, social media with percentage result $5 \%$, and the number of voters with percentage result $11 \%$. Some of the result on the news ww w.neraca.co.id, explains that there are several indicators that have a dominant tendency to influence, level of political participation with the percentage result $4 \%$, social media percentage result $17 \%$, sound the percentage result $25 \%$, and the number of voters percentage result with 
value $22 \%$. On the news www.kumparan.com several indicators that have a dominant tendency to influence, level of political participation percentage result $16 \%$, political issues with the percentage result $42 \%$, and social media the percentage result $17 \%$. On the news www.kompasiana.com several indicators that have dominant tendency influence, level of political participation with percentage result $12 \%$, political issues the percentage result $28 \%$, social media with the percentage result $35 \%$, sound the percentage result with value $8 \%$, and the number of voters the percentage result $27 \%$. On the news www.kompas.com, several indicators that have dominant tendency influence, level of political participation with percentage result $50 \%$, political issues with percentage result $28 \%$, social media with percentage result $17 \%$, sound the percentage result $16 \%$, and the number of voters with percentage result $11 \%$.

The contribution of political participation is a factor affecting the contribution of millennials in the success of the 2019 elections in Indonesia. Based on the data above, several indicators have a very important value in the success of the 2019 elections. First, the level of political participation. According to Samuel P. Huntington and Joan M. Nelson, "Political participation is an activity of citizens that is part of the actions of individuals who are meant to influence decision-making by the government. And participation can also be individual or collective, organized or spontaneous, steady or sporadic, peaceful or violent, legal or illegal, effective, or ineffective. " (Anwar, 2014)

If viewed based on the level of political participation, it greatly affects various aspects of activities in the election. It is known that the millennial generation is a major factor in increasing political participation. As political participation has increased, the success of the election can make the 2019 elections successful in Indonesia. In the interview question and answer session Wednesday, July 1, 2020, at 10:00 WIB to Finish through Zoom Meeting a public discussion held by the government science, Muhammadiyah University of Tangerang, Faculty of Social Sciences and Political Sciences, Government Science Study Program with one of the keynote speakers Neni Nurhayati as Executive Director of Democracy and Electoral Empowerment Partnership, discussing the political participation of the millennial generation in the election said :

"The millennial generation in Indonesia in the 2019 general election reached $40 \%$ of the number of voters. This is positive for the 2019 election because a large number of millennials can get significant votes. Millennials can participate in becoming election organizers and make decisions in politics and are critical monitors of ongoing political issues. As is well known, if literacy is the main thing for millennials, it can be seen that politics is not a problem in the millennial environment. With the presence of millennials, they take an important role as election organizers and oversee every election process. If political participation has increased, then the success of the election can make the 2019 elections successful in Indonesia." (N. Nurhayati, personal communication, July 1, 2020)

Second, sound. According to IDEA, one indicator of the success of the election is voting. In the 2019 Election in Indonesia, the votes of millennials are very important for prospective candidates or political parties. Young voters have the potential to determine votes in participation in the 2019 Election (Carina, 2019). The millennial group contributed at least 23 percent of the total votes in the 2019 Election and the potential for 42 million domestic DPT votes and 42 thousand foreign DPT votes. In 2019, their number is projected to be 23.77 percent of Indonesia's total population of 268 million (Kompas.com, 2018). This means that almost a fifth of the population in Indonesia is a millennial group. The millennial generation shows that they have great power with a lot of numbers so that in the 2019 election the votes of young voters reached 70 to 80 million voters or reached 35 to 40 percent (kompasiana.com, 2019a). Which significantly exceeds the target achieved?

Third, political issues. Political issues can be a tool for millennial contributions. If seen, often before the general election political issues color the political situation in Indonesia. Political issues become a material in the arena to seek support or create images between fellow political parties. Thus, political issues are often discussed by the millennial generation by holding forums or discussions among the millennial generation. As political issues work to 
influence whatever conditions are happening in the 2019 elections so that millennials participate in responding to political issues that are being discussed by them by thinking critically and spontaneously in response to this.

Fourth, social media. According to (Hamidati et al., 2011), "Social media is not just online mass media, because social media has social power which greatly influences a public opinion to develop in society." Social media can influence support or mobilize the mass that is formed. Because social media can form opinions based on the attitudes and behavior of the public or society. "The millennial generation has a very high interest in social media technology in Indonesia, and finally political parties have turned to social media to attract the attention of millennials in the 2019 elections in Indonesia. As is well known, social media can influence the formation of masses based on various users of the same media, there will be the formation of opinions, changes in one's mindset in determining people's attitudes and behavior. Because social media will be very easy to find information in the form of short text or descriptions in other users. Thus social media can influence millennials to convince choices in the 2019 elections in Indonesia.

Fifth, the number of voters. In the 2019 elections in Indonesia, the number of millennials has become an important asset for candidate candidates or political parties to attract the sympathy of millennials in winning the 2019 election vote. According to Sarah Nuraini Siregar, based on the results of the LIPI survey, there is around 35 percent to 40 percent of voters in the 2019 election who are dominated by millennial voters with a total of 80 million out of 185 million voters. Thus the results of the votes given by millennials will be very significant, seeing that their large number will affect the contribution of the 2019 elections in Indonesia.

Items clustered by word similarity

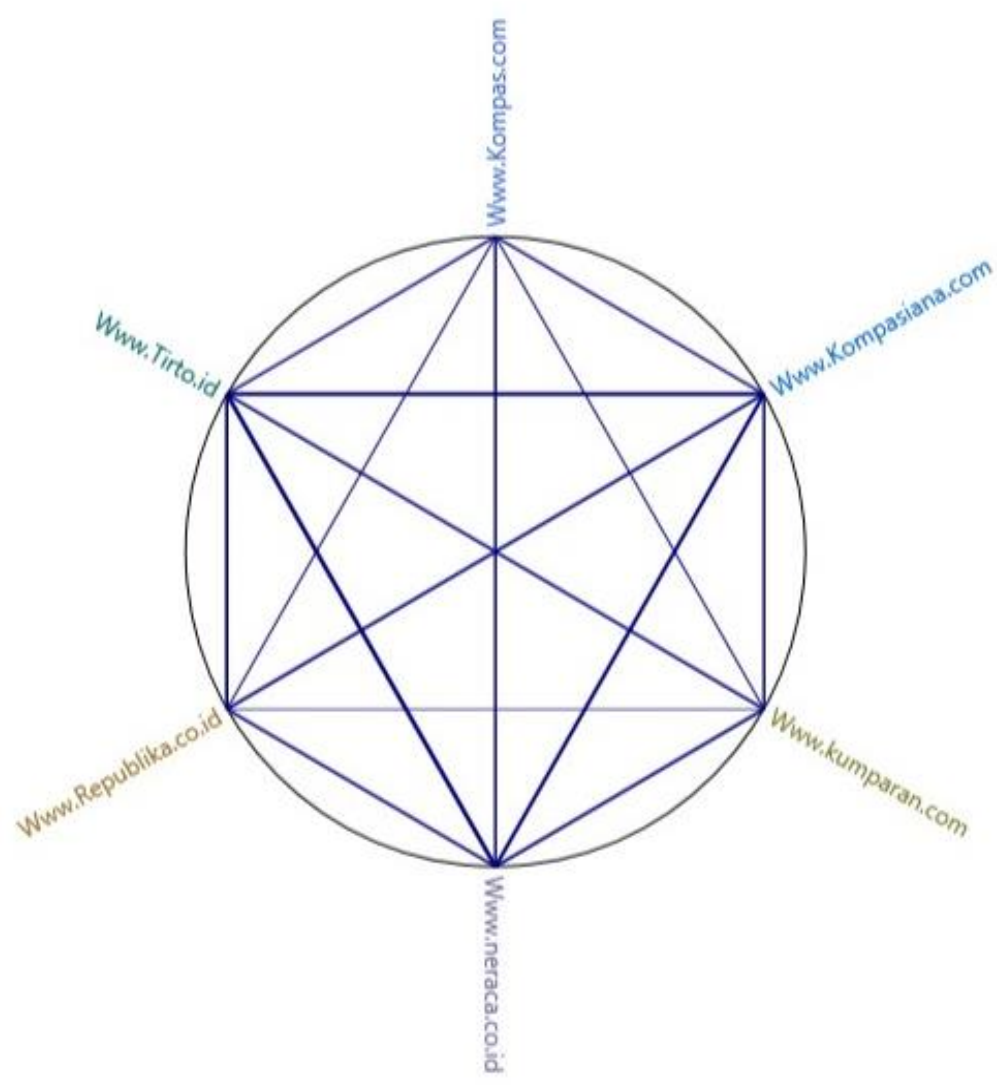

Figure.3 Cluster Analysis

Source: (Cluster Analysis with Nvivo 12 Plus, 2020) 
Based on figure. 3 apart from showing the connectivity between several media and getting some of the problem variables that exist in participation, cluster analysis also shows that the high and low value of the connectivity density (number of connecting lines) between the relevant media and selected according to the popularity of the media. The cluster analysis above states that the factors that influence the contribution of millennials in the success of the 2019 elections in Indonesia are two variables, namely first, millennial characteristics with indicators based on character, labeling effects, period effects, individualism, and age vulnerability. Second, the contribution of millennial political participation with indicators of political issues, number of voters, social media, votes, level of political participation. The picture above shows that there is a content similarity value from several media websites that are formed with each media being interconnected between the number of connecting lines. The online media website, namely, www.kompas.com, www.kompasiana.com, www.kumparan.com, www.neraca.co.id, www.republika.co.id, www.tirto.id, has some connecting lines that indicate a content from each media to produce narrative and opinion on the 2019 election from informants related to the contribution of millennials in the success of the 2019 elections in Indonesia.

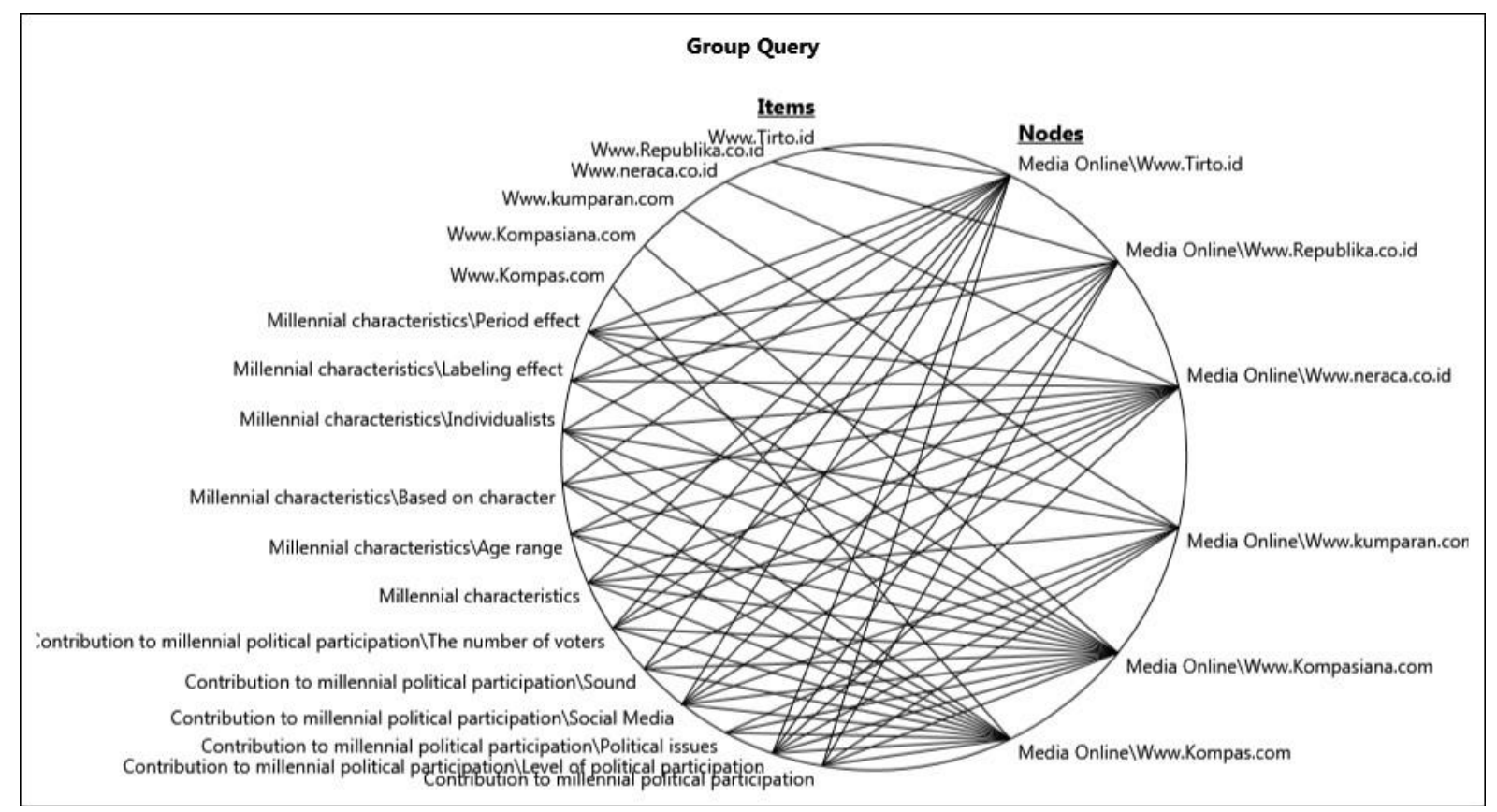

Figure.4 Group Query

Source: (Group Query with Nvivo 12 Plus, 2020)

From the figure.4 above, the data is processed using the query criteria group which analysis the media content of the website www.kompas.com, www.kompasiana.com, www.kumparan.com, www.neraca.co.id, www.republika.co.id, www.tirto.id Of these variables are influenced by several indicators, the first variable is millennial characteristics such as character, labeling effect, period effect, individualism, and age vulnerability. Thus, millennial characteristics are the initial formation of a factor that can affect other factors. The second variable is the contribution of millennial political participation such as political issues, number of voters, social media, votes, and level of political participation. Based on the data, the second variable becomes a factor that can affect the whole. So based on these problem variables, it can create interrelations between the first and second variables that can affect each other.

\section{CONCLUSION}

Based on the conclusion of the contribution of millennials in the success of the 2019 election in Indonesia, some factors affect certain aspects. One of the influencing factors is the characteristics of millennials who tend to be individualistic and have an apathetic nature and do 
not care about discussions that lead to politics. In Indonesia, general elections cannot be separated from the existence of political participation because if the amount of political participation can meet the standard contribution the number of people participating in determining their voting rights. Millennials are one of the supporting factors to contribute to the 2019 elections in Indonesia. Millennial voters can contribute by using social media to share opinions or socialize, vote for candidate candidates, and take part in the implementation of the 2019 elections. Furthermore, the factor of the number of millennial voters in the 2019 elections in Indonesia is an important role with a significant number of millennials around 35 percent. up to 40 percent with a total of around 80 million out of 185 million voters to get votes in the 2019 elections. Social media has played an important role in the 2019 general elections in Indonesia, especially for millennials. As is well known, social media can influence various users of the same media, there will be opinion formation in changing one's mindset to determine people's attitudes and behavior. This means that one of the social media factors has an important influence value because millennials are consciously contributing to have a big effect on the success of the 2019 elections in Indonesia.

\section{REFERENCES}

Abdi, A. P. (2018, Desember). Hasil Survei Lipi: 40 Persen Suara Di Pemilu Didominasi Milenial. Tirto.Id. Https://Tirto.Id/Hasil-Survei-Lipi-40-Persen-Suara-Di-Pemilu-DidominasiMilenial-Dbgf

Al Walidah, I. (2017). Tabayyun Di Era Generasi Millennial. Jurnal Living Hadis, 2(1), 320.

Amarullah, A., \& Firmansyah, T. (2018, September 6). Jppr: Pemilih Milenial Kunci Pemilu 2019 Berkualitas / Republika Online. Republika.Co.Id. Https://Republika.Co.Id/Berita/Nasional/Politik/18/09/06/Pelltj377-Jppr-PemilihMilenial-Kunci-Pemilu-2019-Berkualitas

Andriadi, F. (2016). Demokrasi Di Tangan Netizen Tantangan Dan Prospek Demokrasi Digital. Rmbooks.

Ansori, L. (2017). Telaah Terhadap Presidential Threshold Dalam Pemilu Serentak 2019. Jurnal Yuridis, 4(1), 15. Https://Doi.Org/10.35586/.V4i1.124

Anwar, A. (2014). Politik Pencitraan-Pencitraan Politik. Graha Ilmu.

Baderi, F. (2018, September 14). Menerka Suara Pemilih Milenial Di Pilpres 2019. Http://Www.Neraca.Co.Id/Article/106223/Menerka-Suara-Pemilih-Milenial-Di-Pilpres2019

Bps. (2013). Proyeksi Penduduk Indonesia Berdasarkan Sensus Penduduk 2010-2035. Bps Statistics Indonesia.

Brading, R. (2017). Taiwan's Millennial Generation: Interests In Polity And Party Politics. Journal Of Current Chinese Affairs, 46(1), 131-166. Https://Doi.Org/10.1177/186810261704600106

Brandao, C. (2015). Qualitative Data Analysis With Nvivo,By P. Bazeley And K. Jackson, Qualitative Research In Psychology. Routledge, 00, 1-3.

Carina, J. (2019, April 18). Partisipasi Pemilu Naik, Menurut Ma'ruf Karena Masyarakat Semakin Sadar

Politik.

Https://Nasional.Kompas.Com/Read/2019/04/18/15235861/Partisipasi-Pemilu-NaikMenurut-Maruf-Karena-Masyarakat-Semakin-Sadar

Charta, P. (2018). Tahun Politik Milik Generasi Millennial. Https://Www.Qureta.Com/Post/Generasi-Milenial-Dan-Digitalisasi

Delmana, L. P., Zetra, A., \& Miko, A. (2019). Konstruksi Indikator Dan Formula Penilaian Kualitas Pemilu Di Indonesia. Jppuma Jurnal Ilmu Pemerintahan Dan Sosial Politik Universitas Medan Area, 7(1), 60. Https://Doi.Org/10.31289/Jppuma.V7i1.2000

Eacea. (2012). Political Participation And Eu Citizenship: Perceptions And Behaviours Of Young People. Eacea (Education, Audiovisual And Culture Executive Agency). Https://Ec.Europa.Eu/Assets/Eac/Youth/Policy/Documents/PerceptionBehaviours_En.Pdf

Efriza. (2012). Political Explorer Sebuah Kajian Ilmu Politik. Alfabeta. 
Efriza, Y. R. (2015). Pengantar Ilmu Politik. Intrans Publishing, Malang.

Efriza, Y. R. (2017). Hanbook Sistem Politik Indonesia: Mempelajarii Teori Dan Praktik. Intrans Publishing.

Fitri, A. (2018). Dinamika Dan Tantangan Jelang Pemilu Presiden Tahun 2019. Jurnal Ilmu Pemerintahan, 3(01), 19.

Hamidati, A., Fajar, A., Ayu, D., Kartika, S., Melissa, E., Junaedi, F., E. Luik, J., Santosa, P. H., Utari, P., Rahardjo, T., Darmastuti, R., R. Tambunan, S., Yusuf, I. A., \& Nur Ra, G. A. (2011). Komunikasi 2.0. Mata Padi Pressindo.

Hani S.P, R. (2013). Partisipasi Politik Etnis Tionghoa Dalam Pemilukada Tahun 2009 (Studi Kasus Desa Kragan Kec. Kragan Kab. Rembang). Jurnal Pardigma, 1(1), 1.

Kompas.Com. (2018, July 5). Suara Generasi Millennial Saat Potensial Dalam Pemilu. Https://Nasional.Kompas.Com/Read/2018/05/07/15570811/Suara-Generasi-MilinealSangat-Potensial-Dalam-Pemilu

Kompasiana.Com. (2019a, February 21). Partisipasi Anak Muda Pada Pemilu 2019 Halaman All-Kompasiana.Com.

Https://Www.Kompasiana.Com/Minnie/5c6eac7612ae947345673f84/PartisipasiAnak-Muda-Pada-Pemilu-2019?Page=All

Kompasiana.Com. (2019b, March 28). Peran Generasi Milenial Dalam Pemenangan Pemilu 2019 Halaman All-Kompasiana.Com. Https://Www.Kompasiana.Com/Saada/5c9c938a95760e29370f9462/Peran-GenerasiMillenial-Dalam-Pemenangan-Pemilu-2019?Page=All

Kumparan.Com. (2018). 3 Bentuk Karakteristik Partisipasi Politik Generasi Milenial. Kumparan.Com. Https://Kumparan.Com/Millennial/3-Bentuk-Karakteristik-PartisipasiPolitik-Generasi-Milenial-1540631181597860194

Labolo, M., \& Ilham, T. (2015). Partai Politik Dan Sistem Pemilihan Umum Di Indonesia: Teori, Konsep Dan Isu Strategis. Rajagrafindo Persada.

Laksmitha, N., \& Susanto, E. H. (2019). Partisipasi Politik Generasi Milenial Di Instagram Dalam Pemilu 2019. Koneksi, 3(1), 250. Https://Doi.Org/10.24912/Kn.V3i1.6218

Medenica, V. E. (2018). Millennials And Race In The 2016 Election. The Journal Of Race, Ethnicity, And Politics, 3(1), 55-76. Https://Doi.Org/10.1017/Rep.2017.33

Media Kompas, C. (2018, September 17). Beda Cara Generasi Milenial Dalam Politik. Kompas.Com. Https://Nasional.Kompas.Com/Read/2018/09/17/19090001/BedaCara-Generasi-Milenial-Dalam-Politik

Mistar, \& Satmoko Adi, A. (2015). Tingkat Partisipasi Politik Pemilih Pemula Dalam Pelaksanaan Pemilu Legislatif 2014 Dprd Sampang. Kajian Politik Dan Kewarganegaraan, 01(03), 120.

Mochtar, C. O. (2019). Factors Affecting Millennial Generation Voting Decision In The 2019 General Election In Surabaya. Jurnal Politico, 19(2), 16.

Nurhayati, N. (2020, July 1). Menyoal Pilkada Serentak 2020: Perspektif Penyelenggara Dan Masyarakat Sipil [Personal Communication].

Nuryanti, S. (2015). Menyiapkan Tata Kelola Pemilu Serentak 2019. Jurnal Penelitian Politik, 12, 14.

Nw, 1615 L. St, Suite 800washington, \& Inquiries, D. 20036usa202-419-4300 | M.-857-8562 | F.419-4372 | M. (2010, February 24). Millennials: Confident. Connected. Open To Change. Pew Research Center: Internet, Science \& Tech. Https://Www.Pewresearch.Org/Internet/2010/02/24/Millennials-ConfidentConnected-Open-To-Change/

Nw, 1615 L. St, Washington, S. 800, \& Inquiries, D. 20036 U.-419-4300 | M.-419-4349 | F.-4194372 | M. (2014, March 7). Millennials In Adulthood. Pew Research Center's Social \& Demographic Trends Project. Https://Www.Pewsocialtrends.Org/2014/03/07/Millennials-In-Adulthood/

Sacipto, R. (2019). Tinjauan Wawasan Kaum Milineal Menghadapi Pelaksanaan Pesta Demokrasi. $1,10$. 
Satria, H. W. (2018). Studi Observasi Terhadap Penggunaan Aplikasi Line Oleh Generasi Millenial. 1,9 .

Surbakti, A. R., \& Nugroho, K. (2015). Studi Tentang Desain Kelembagaan Pemilu Yang Efektif. Kemitraan Bagi Pembaruan Tata Pemerintahan.

Surya Putra, Y. (2016). Theoritical Review : Teori Perbedaan Generasi. Among Makarti, 9(18), $123-134$.

Tirto.Id. (2018, September 12). Sana-Sini Ngaku Milenial, Bagaimana Peta Milenial Indonesia? Tirto.Id. Https://Tirto.Id/Sana-Sini-Ngaku-Milenial-Bagaimana-Peta-Milenial-Indonesia$\mathrm{Cx} 5 \mathrm{w}$

Wall, A., Ella, A., W. Dundas, C., Rukambe, J., \& Staino, S. (2016). Electoral Management Design: The International Idea Handbook. Terjemahan Institute Demokrasi Dan Asistensi Demokrasi 2016, Perludem. International Idea. 